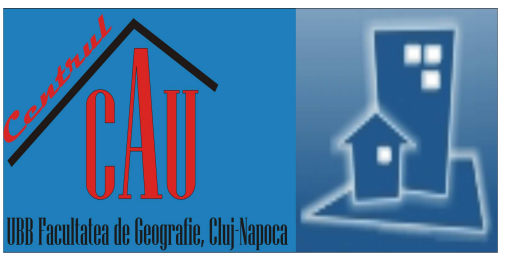

\title{
Vernacular Architecture as Cultural Heritage: An Interpretation of Urban Vernacular 'Bangla Baton' Houses of Sylhet City, Bangladesh
}

\author{
Kawshik SAHA1*, Rezwan SOBHAN', Mohammad NAHYAN', Sadiya Afrin MAZUMDER \\ *Corresponding author \\ ${ }^{1}$ Shahjalal University of Sciences and Technology, Department of Architecture, Sylhet, BANGLADESH \\ $\triangle$ kawshik-arc@sust.edu (D) https://orcid.org/oooo-ooo3-1886-2445 \\ $\triangle$ arc.sobhan@gmail.com (D) https://orcid.org/oooo-0oo2-0030-3656 \\ $\triangle$ ar.nahyan@gmail.com (D) https://orcid.org/oooo-ooo2-4443-4631 \\ $\triangle$ sadiaasworna@gmail.com (D) https://orcid.org/oooo-00o2-4372-1612 \\ DOI: 10.24193/JSSP.2021.1.04 \\ https://doi.org/10.24193/JSSP.2021.1.04
}

K e y w o r d s: Bangla Baton house, cultural heritage, vernacular architecture, ethnography, sustainability, conservation management

\begin{abstract}
A B S T RA C T
'Bangla Baton' house is a unique urban vernacular archetype that has historically evolved from the Assamese style houses and later modified by adapting to the local context of the Sylhet region. These types of houses bring out the rich urban history of Sylhet city and carry significant values of the socio-cultural, environmental, and architectural aspects of the region. Unfortunately, due to high land prices, rapid urbanization, and population growth, they are at high risk of destruction. This research is an interpretation to enhance motivation to make the local community understand the heritage values of this house type. The key objective of this research is to introduce this house form as an element of 'Cultural Heritage' by identifying and analyzing its values and assessing the sustainability factors in terms of the environmental and climatic issues of the region. Because of the lack of sufficient literature data, field surveybased observational data were used as the primary approach to identify the significant elements of 'Cultural Heritage' of 'Bangla Baton' house types. Criteria and indicator-based approach were adopted to assess heritage significances. This paper provides an insight into the urgency of initiating proper planning and conservation management to save this valuable heritage element from extinction. By identifying and analyzing 'Cultural Heritage' elements, this study will help generating guidelines for selecting the appropriate methodologies and tools for further assessment of the identified values of this unique heritage form as part of sustainable conservation management and planning.
\end{abstract}

\section{INTRODUCTION}

Bangladesh, with its subtropical monsoon climate, showcases an array of vernacular building practices that form a significant base of architectural quality throughout the country. As a north-eastern province of Bangladesh, Sylhet has its traditional urban fabric, with unique styles of urban vernacular heritage.
The regional pattern of the microclimate, socio-cultural context, and building technology has determined the emergence of a new type of indigenous housing culture in this region. But present-day unplanned urban growth, the adverse technological development and the high population density restrict the continuity of organic urban patterns, including its vernacular heritage like 'Bangla Baton' houses (Fig. 1). 'Bangla 
Baton' houses are a distinct type of Assamese-style vernacular houses in different parts of the Sylhet region (Kaushik and Babu, 2009). Most of these houses were built during the British colonial era and used to bear a unique regional identity combining British techniques and local vernacular style. Though several houses are still found to be used by inhabitants, they are at high risk of disappearance. The owners of these houses are being influenced to make inappropriate space modifications and sometimes intend to demolish these significant house structures. The key reasons behind the scene are high land prices, rapid urbanization, population growth, change of profession of the inhabitants, etc. The ignorance of historical significance and the absence of conservation planning and management policies of the government agency authority can also be considered a great threat against the survival of these significant house structures. In Sylhet city, there has been a growing concern among inhabitants that rapid urbanization is destroying the cultural identity of the historic urban landscape. This acute awareness of losing cultural identity gives a reason for this research. By interpreting the 'Bangla Baton' house, this research aims to identify the 'Cultural Heritage Significance' of these houses by soliciting a methodological intervention of architectural properties. Several houses were assessed, documented, and analyzed to identify their significances. The research also conducts a sustainability assessment of this vernacular form to identify how understanding this architectural heritage might influence the modern design. The authors expect this research to yield a needed foundation for further conservation efforts to save these unique vernacular houses.

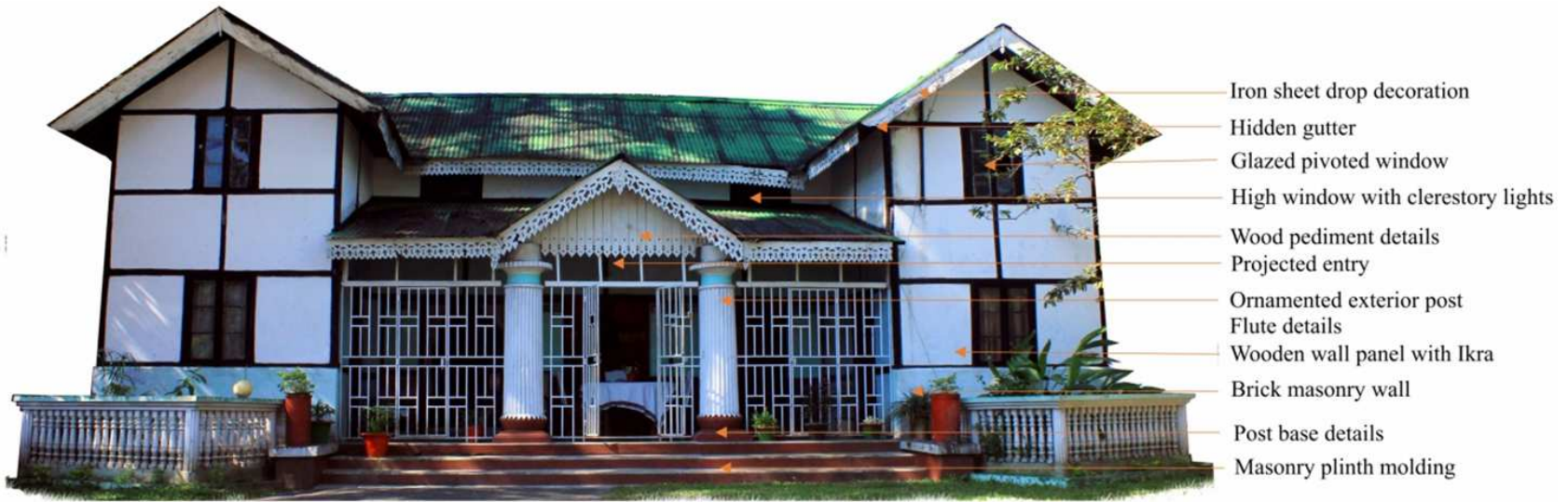

Fig. 1. An example of Bangla Baton house in Sylhet city. Elevation of Rafiqul Haque Residence, Hawa Para, Sylhet (1913).

\section{INTERPRETATION OF THE VERNACULAR HOUSE FORM AS 'CULTURAL HERITAGE'}

Vernacular architecture is a direct representation of people and their culture. In human history, vernacular dwellings have developed in response to climate challenge, building materials, and cultural norms in a given location (MOIE, 2019). Rapoport (1969) defines vernacular architecture as "...the folk tradition, on the other hand, as the direct and oneself-conscious translation into the physical form of a culture, its needs and values, and the desires, dreams, and passions of people" (Rapoport, 1969). Obviously, vernacular architecture differently develops within regions according to the community's cultural norms, customs, and traditional beliefs. Oliver (2006) defined vernacular buildings as cultural heritage, since vernacular houses are sources of both tangible and intangible values of the society (Oliver, 2006). The ICOMOS Charter on built vernacular heritage has given significant importance to the study and conservation of vernacular built forms as part of the cultural heritage (ICOMOS, 1999). The charter stated “...the built vernacular heritage is important; it is the fundamental expression of the culture of a community, of its relationship with its territory and, at the same time, 36 the expression of the world's cultural diversity...Due to the homogenization of culture and of the global socioeconomic transformation, vernacular structures all around the world are extremely vulnerable, facing serious problems of obsolescence, internal equilibrium and integration" (ICOMOS, 1999).

Traditional vernacular archetypes have a direct correlation with the socio-cultural context of any region. Cultural heritage directly influences traditional house activities. As a South Asian Muslim majority country, in Bangladesh traditional domestic archetypes are profoundly shaped by occupation, gender issues, spiritual beliefs (AL-Mohannadi et al., 2020). In line with existing literature, it is understandable that vernacular architecture is deeply associated with cultural heritage by reflecting cultural identity through spaces and forms. However, in developing country scenarios, vernacular houses are often taken rather as primitive and insignificant than the so-called modern houses. These traditional houses are an element of cultural heritage as they contain cultural elements, traditional knowledge systems, and societal identity across different regions.

The identification and assessment of heritage properties are globally accepted as the primary approach for conservation planning and management. 
In order to understand the heritage significances of any vernacular dwelling, the proper identification and assessment of all of their elements are necessary. The associated cultural landscapes and the interrelationships between people, environment and place that contribute to its significance need to be well examined. (ICOMOS, 2017). Vernacular housing culture is deeply associated with intangible cultural heritage elements like performing art, crafting, mythology, ritual customs, etc. (Christie, 2017). Much more, the cultural significance of vernacular house form may also be found in its tangible attributes, including physical location, views, form and spatial relationships, colour schemes, construction systems and aesthetic qualities. Significances may also lie in the use, historical, social, scientific, or spiritual associations of the particular house form.

In the context of the Sylhet region, 'Bangla Baton' houses are living shreds of evidence of the cultural heritage in terms of historical significance, architecture, and other associated intangible values. At present, this significant housing style is threatened by a lack of awareness for proper conservation measures. It is essential to take proper steps to conserve, interpret, and manage it well for the future generations. This paper proposes an approach to generate appreciation and care regarding the 'Bangla Baton' house among the local government and community by introducing it as an element of 'Cultural Heritage' due to its significance.

\section{METHODOLOGY}

This research adopted an ethnographic research approach to collect primary data related to this study. According to Fielding (1993) ethnography entails the study of behaviour in a natural setting, 'getting the seat of your pants dirty in the actual world, not the library'. In particular, an ethnographic approach to study any architecture allows for a naturalistic on-site investigation of influences that affect the shape of the living environment. Thus, ethnography, as a branch of the qualitative research process, can be used to the cultural interpretation of a vernacular heritage property (Groat and Wang, 2001). To be more specific, based on Othman (2004) the ethnographic methodological approach for collecting data of this research consists of:

a). Participant observation, where on-site investigations are carried out by researchers.

b). Observational research, observing and questioning the inhabitants of the houses to know how they behave and act towards the environment.

c). Contextual inquiry to ask how the house form adapts to the existing topography, environmental, climatic settings.

d). Componential analysis by understanding space meaning and how this is connected to the family or cultural value.

The methodological part can be divided into three phases (Fig. 2).
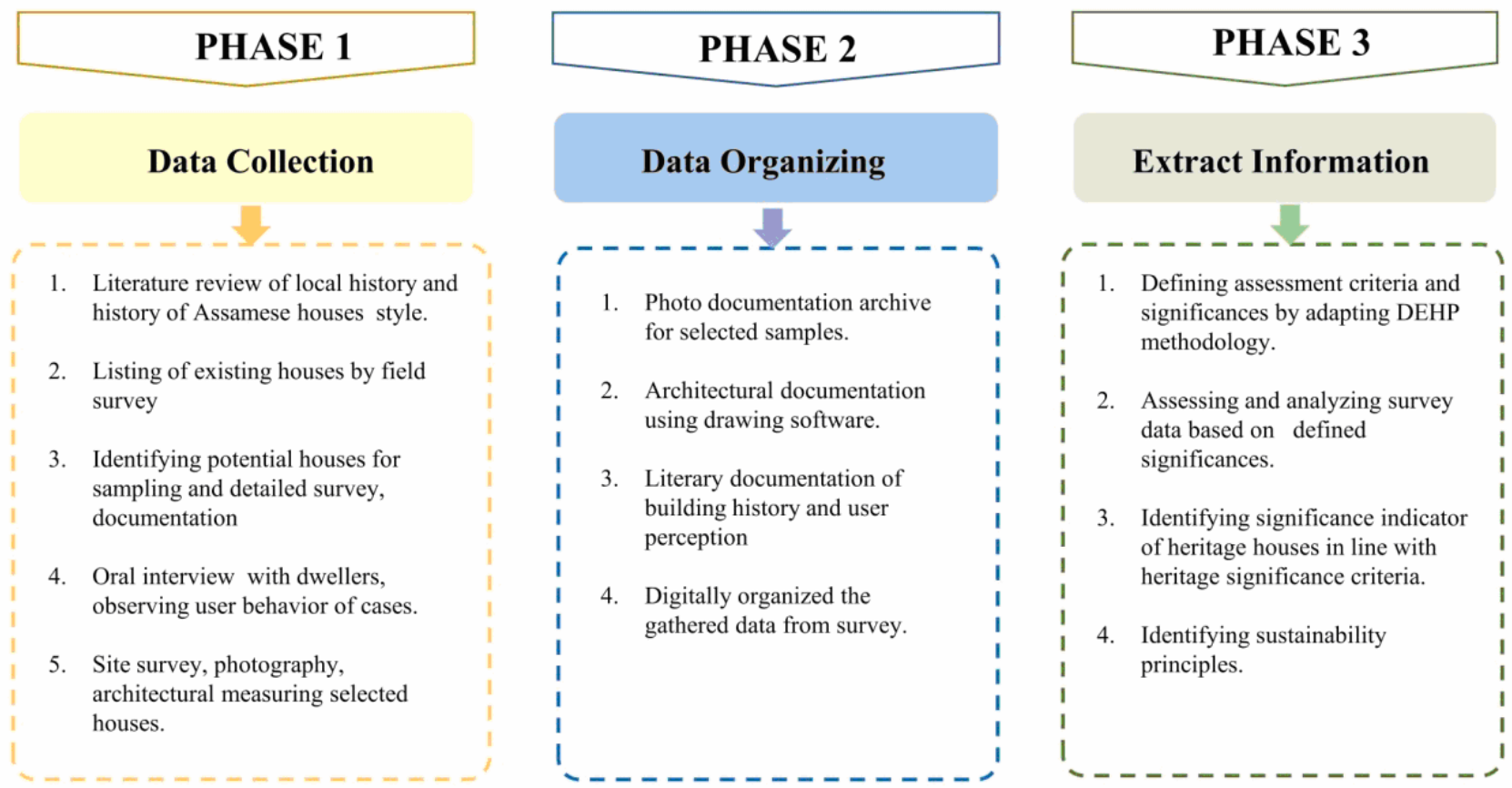

Fig. 2. Methodological phases of the research.

In the first and the second phases, potential heritage buildings were identified and documented. As the study area, the core urban area of old Sylhet was selected according to the aim of this study (Fig. 3). By physical survey and observation, it was identified that most of the examples of 'Bangla Baton' house structures are within the periphery of old Sylhet. Authors identified nearly 45 'Bangla Baton' houses still surviving 
in various conditions. Out of them, several houses were selected for further documentation based on their physical condition and function. The houses were surveyed with measuring tools. Photographs were taken to record architectural details. Inhabitants were interviewed orally and recorded in digital format.

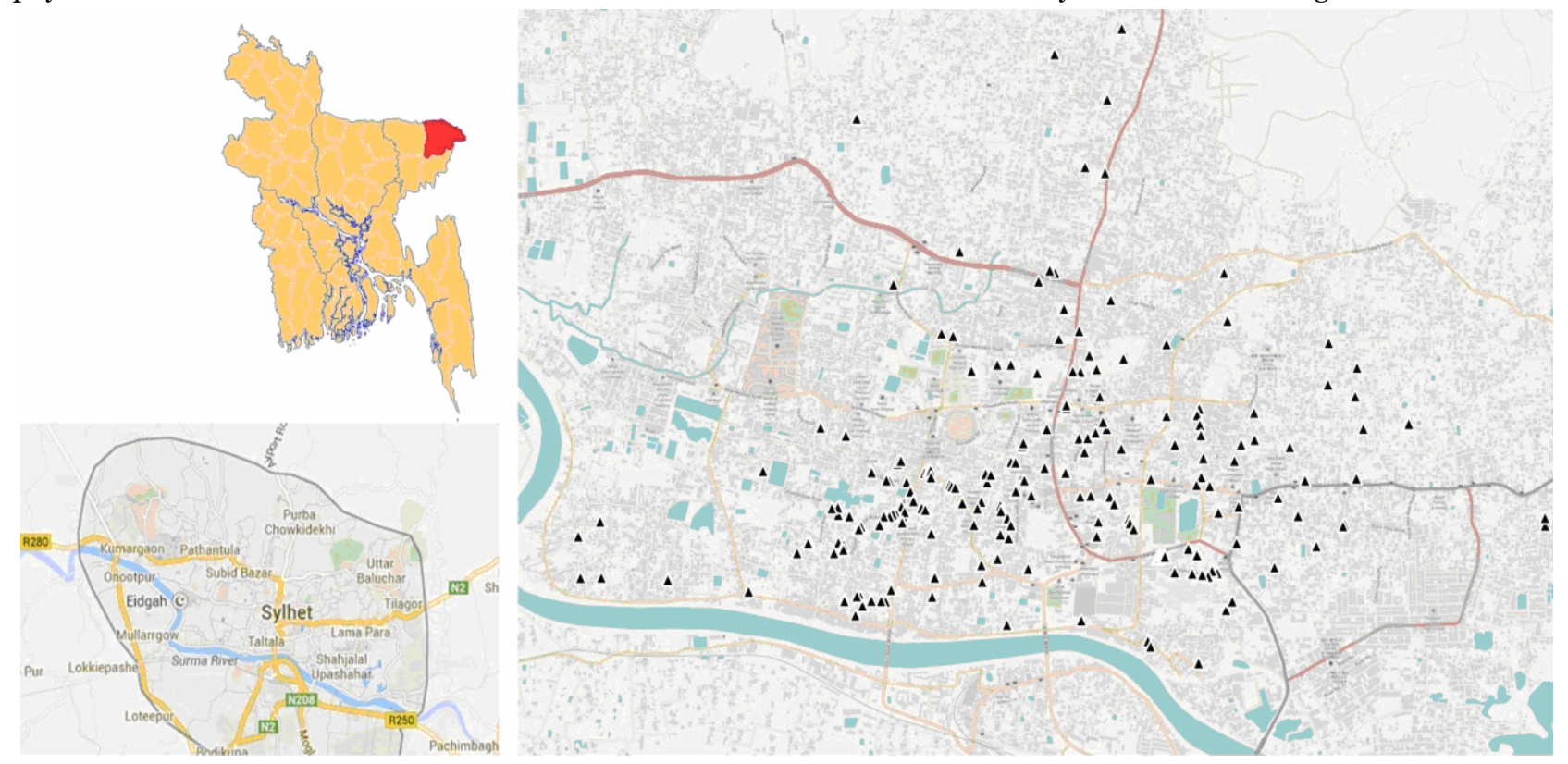

Fig. 3. Map showing the study area and location of Assamese style houses in Sylhet city.

Table 1. Criteria for assessing cultural heritage significances of Bangla Baton houses.

\begin{tabular}{|c|c|c|}
\hline Criteria & Criteria description & Significances to assess \\
\hline Criterion 1 & $\begin{array}{l}\text { The place or area is important in demonstrating the evolution or pattern of the local } \\
\text { government area's history }\end{array}$ & $\begin{array}{l}\text { Historical significances } \\
\text { Scientific significances }\end{array}$ \\
\hline Criterion 2 & $\begin{array}{l}\text { The place or area demonstrates rare, uncommon, or endangered aspects of the local } \\
\text { government area's cultural heritage }\end{array}$ & $\begin{array}{l}\text { All aspects of cultural } \\
\text { heritage significance }\end{array}$ \\
\hline Criterion 3 & $\begin{array}{l}\text { The place or area has the potential to yield information that will contribute to an } \\
\text { understanding of the local government area's history }\end{array}$ & $\begin{array}{l}\text { Historical significances } \\
\text { Scientific significances }\end{array}$ \\
\hline Criterion 4 & $\begin{array}{l}\text { The place or area is important in demonstrating the principal characteristics of a } \\
\text { particular class of cultural places }\end{array}$ & $\begin{array}{l}\text { Architectural significance } \\
\text { Historical significance }\end{array}$ \\
\hline Criterion 5 & $\begin{array}{l}\text { The place or area is important because of its aesthetic significance to the local } \\
\text { community }\end{array}$ & $\begin{array}{l}\text { Aesthetic significance } \\
\text { Architectural significance }\end{array}$ \\
\hline Criterion 6 & $\begin{array}{l}\text { The place or area is essential in demonstrating a high degree of creative or technical } \\
\text { achievement at a particular period }\end{array}$ & $\begin{array}{l}\text { Aesthetic significance } \\
\text { Architectural significance } \\
\text { Other significance }\end{array}$ \\
\hline Criterion 7 & $\begin{array}{l}\text { The place or area has a strong or special association with a particular community or } \\
\text { cultural group for social, cultural, or spiritual reasons }\end{array}$ & Social significance \\
\hline Criterion 8 & $\begin{array}{l}\text { The place or area has a unique association with the life or work of a particular person, } \\
\text { group, or organization of importance in the area's history }\end{array}$ & Historical significances \\
\hline
\end{tabular}

Source: Adapted from DEHP (2013).

The physical survey data were digitally documented with computer-aided drawings and $3 \mathrm{D}$ model development (see Fig. 1). To identify and classify the 'cultural heritage significance' of 'Bangla Baton' houses, a 'criteria' and 'indicator' based approach was applied in this study. A set of criteria were established based on which cultural heritage significance of Baton houses can be measured. These criteria were measured with 'significance indicators' by which those criteria can be met. The collected survey data were assessed and analyzed based on the significances (historical, architectural, scientific, aesthetic, and socio-cultural). Unfortunately, the heritage protection act of Bangladesh does not provide any specific guidelines for prioritizing vernacular buildings as architectural heritage.

Thus, the authors had to depend on other external sources of best practices. To assess the cultural heritage significances of 'Bangla Baton' houses, the authors prepared a set of criteria and indicators by adopting references from various documents regarding heritage assessment guidelines (see Table 1). The basic assessment framework mostly followed the guidelines 
Vernacular Architecture as Cultural Heritage:

An Interpretation of Urban Vernacular 'Bangla Baton' Houses of Sylhet City, Bangladesh

Journal Settlements and Spatial Planning, vol. 12, no. 1 (2021) 35-49

prepared by the Queensland heritage department (DEHP, 2013). The heritage significances of Baton houses were tested by assessing the historical, aesthetic, architectural, scientific, socio-cultural significances of 'Bangla baton' houses. Table 1 shows the assessment criteria that were drawn to assess the 'cultural heritage significances' of 'Bangla Baton' houses and the significance indicators used for determining those criteria. Using these criteria, in this study, 'cultural heritage significance' can be determined and classified primarily by a descriptive analysis of the data found by a physical survey around the old part of Sylhet city, user perceptions, and in-site observations. This research mainly focuses on identifying the cultural heritage significance and then evaluating the sustainability factors of 'Bangla Baton' houses to increase public awareness.

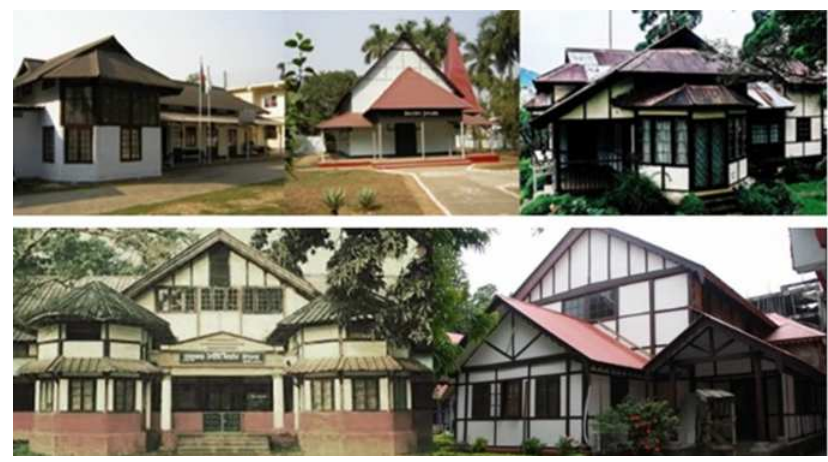

Fig. 4. Baton style houses in Sylhet and Assam province (photographs from various sources).

Historically, Sylhet served as a central administrative city of Assam province from 1874 to 1947 (Hussain, 2014). Because of the shared past with Assam, the historic urban landscape of Sylhet still holds many shreds of evidence from colonial India in terms of cultural heritage, tradition and similar geo-climatic features like hilly topography, heavy monsoon rain and earthquake vulnerability. Therefore, the 'Bangla Baton' style is often classified as a subgroup (a regional version) of the greater Assamese style houses. As a subgroup of the 'Assamese style', the 'Bangla Baton'

\section{RESULTS AND DISCUSSION}

\subsection{Historical significance of 'Bangla Baton' houses in Sylhet}

The 'Bangla Baton' houses are a regional archetype in the greater Sylhet region of Bangladesh. The word 'Bangla' points out the Bengal region, and 'Baton' means wooden planks or bars (Sobhan et al., 2013). 'Bangla Baton' houses are also known as 'Ikra houses' as the walls are often made of a local plant name 'Ikra' reed (Das et al., 2014).

This style was primarily developed during the British colonial India, forming a blended tradition between ethnic identity and modern technology (Archinomy, 2013) (Fig. 4).
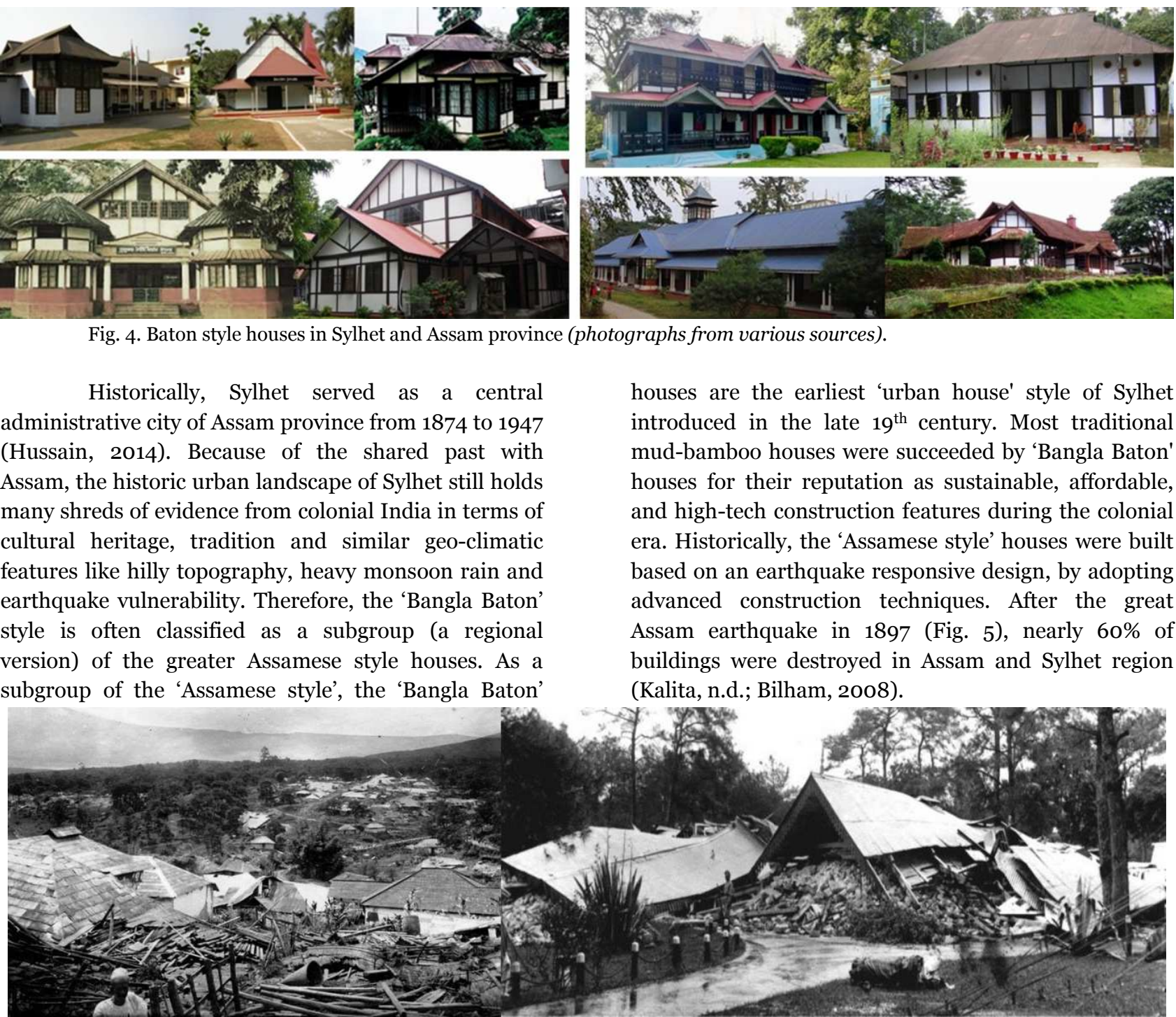

Fig. 5. Photograph of Great Assam earthquake taken by geologist Tom La Touche (source: Bilham, 20o8).

Hence, the British engineers came up with a new construction system to build a lightweight structure to reduce seismic vulnerability. They introduced modern construction techniques like iron joints, light houses are the earliest 'urban house' style of Sylhet introduced in the late $19^{\text {th }}$ century. Most traditional mud-bamboo houses were succeeded by 'Bangla Baton' houses for their reputation as sustainable, affordable, and high-tech construction features during the colonial era. Historically, the 'Assamese style' houses were built based on an earthquake responsive design, by adopting advanced construction techniques. After the great Assam earthquake in 1897 (Fig. 5), nearly 60\% of buildings were destroyed in Assam and Sylhet region (Kalita, n.d.; Bilham, 2008). 
and good framing (Subhankar and Amol, 2013). Most of the houses in Sylhet are more than a hundred years old. However, many are still maintained, changed, and used by the dwellers (Subhankar and Amol, 2013). The authors have identified nearly 45 houses Inside Sylhet city still functioning and another 20 to 30 houses in a shattered state. These houses hold immense importance from a historical viewpoint as it was the first urbandwelling type of the greater Assam and Sylhet region. These houses profoundly influenced the traditional urban morphology of Sylhet city and became an iconic element of the historic urban landscape of Sylhet (Saha et al., 2013; Saha et al., 2020).

\subsection{Architectural significance of 'Bangla Baton' houses}

Determining architectural significance is the process of identifying the principal architectural

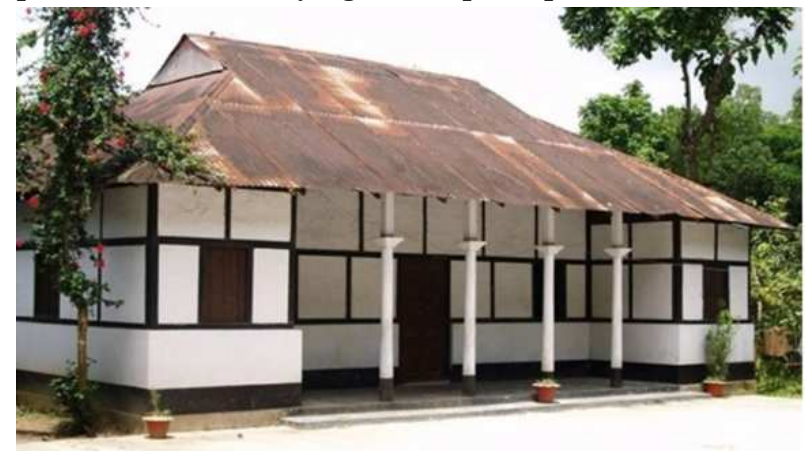

a) House of Abdul Goni Chowdhury.

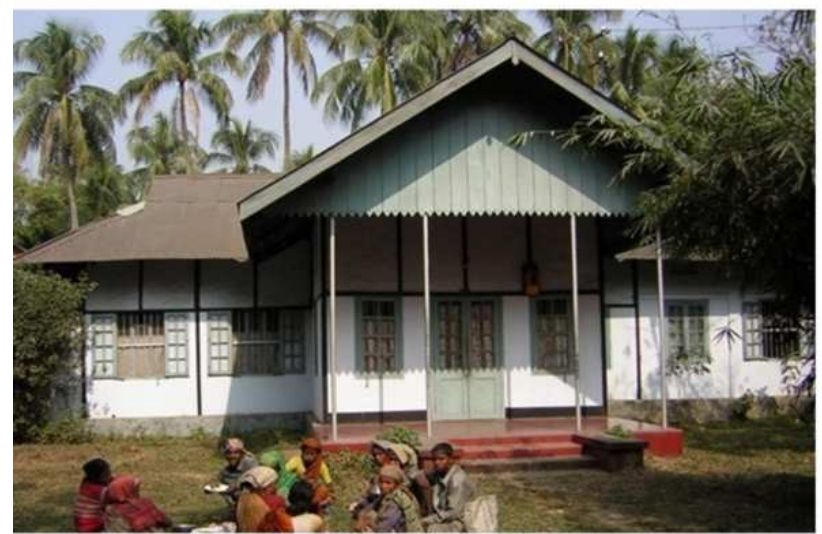

c) House of Mr. Zamin Ahmed characteristics of a place. This significance helps decide if characteristics are essential to understand a class of cultural places into architecture or architectural innovation (DEHP, 2013). The architectural significance also defines the pattern and evolution of the history of a region. The formal expression and planning layout of the 'Bangla Baton' house represent the Sylhet region's architectural and spatial identity, combined with several design innovations and aesthetic values.

House Form. In the case of 'Bangla Baton' houses with a smaller built-up area, the plan is regular and symmetric. These houses are typically singlestoried structures with a unique roofing system, where the indoor and semi-outdoor spaces rest under a single pitch (Fig. 6).

These types of houses are found in common rectangular I shape for single or two-family houses on flatlands. For a multi-family house, the plan is U, L and C shaped (Fig. 7).

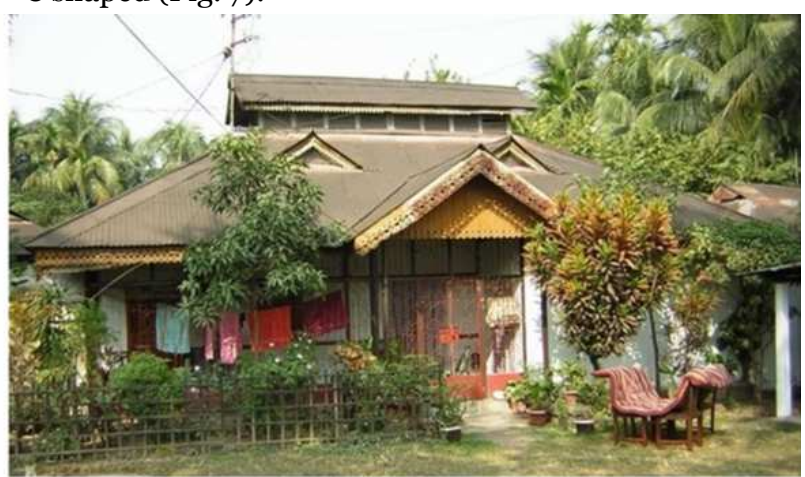

b) House of Dr. M. Choudhury.

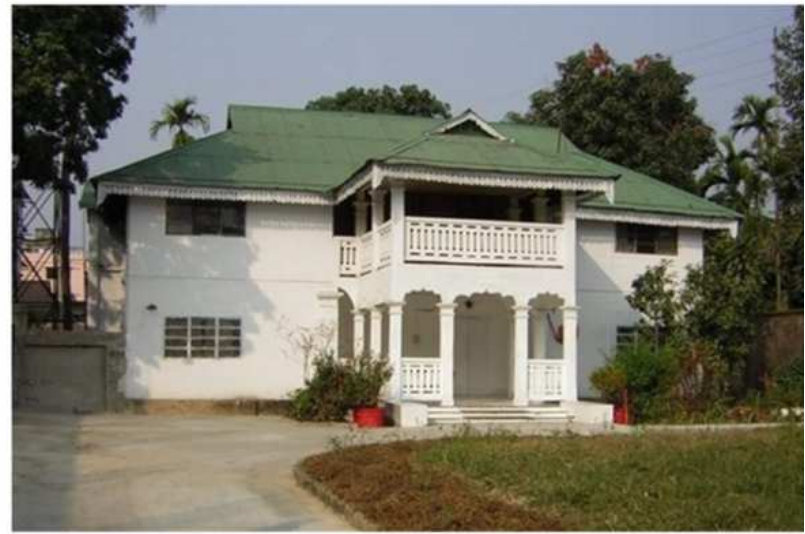

d) House of Late Rasheed Chowdhury

Fig. 6. Example of Bangla Baton houses in Sylhet city (Photo source: Saki Chowdhury).

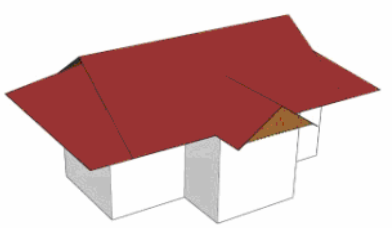

a) $\mathrm{T}$ type shape

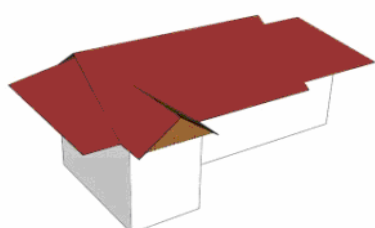

b) L type shape

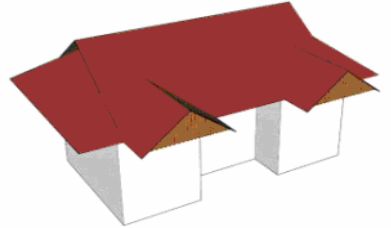

c) U type shape

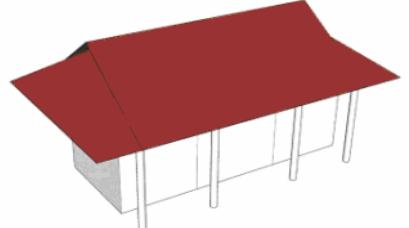

d) I type shape

Fig. 7. Types of Bangla Baton house forms.

In most cases, the building height is loftier than the present single-story structures because of its unique roofing system. The indoor room height is also spacious, varying from 4 to 5 meters in height. This lofty 
Vernacular Architecture as Cultural Heritage:

An Interpretation of Urban Vernacular 'Bangla Baton' Houses of Sylhet City, Bangladesh

Journal Settlements and Spatial Planning, vol. 12, no. 1 (2021) 35-49

space offers better climatic comfort and luxury of space, with or without the provision of access to the attic. The building elevation can be divided into three parts, namely base, body, and roof.

Planning layout. The common module of the 'Bangla Baton' house follows a general spatial organization of two distinct zones. In most of the house plans, the separation between the semi-private and private zones is clearly observed and strictly maintained. These two distinct zones are separated by a buffer, functionally used as 'inner court'. The location of the houses depends on accessibility because of the compact urban situation. However, the private house's climatically and socially desirable location is East and outdoor to semi-outdoor, and indoor spatial sequence is maintained strictly. The approach to the semi-private zone is through the outhouse, and to the private zone, the access is indirect and hidden (Fig. 8). The outhouse contains a projected porch to create a proper entry approach and an inviting appearance. The out-house portion is used as a public living area, where the seating and living arrangement for guests, private chambers and stores, etc., are found. The private zone includes the bedrooms, dining, kitchens, ponds, and lavatory with wash areas. In singles residences, the sequence is similar, as the semi-public functions are placed at the front. However, in both types, the outer form has a projected porch, thus creating an inviting character. The typical 'Assamese style houses' were changed by adapting to the Assam region's climatic and contextual issues. A continuous veranda runs along the full length of the front facade. If constructed in the hilly areas, the veranda is placed as to face the slope. 'The open inner courtyard' and the extensive use of the 'semi-outdoor veranda' as the common circulation and entry porch are examples of design innovation that can be considered as an essential contribution to the built environment of the Sylhet region.
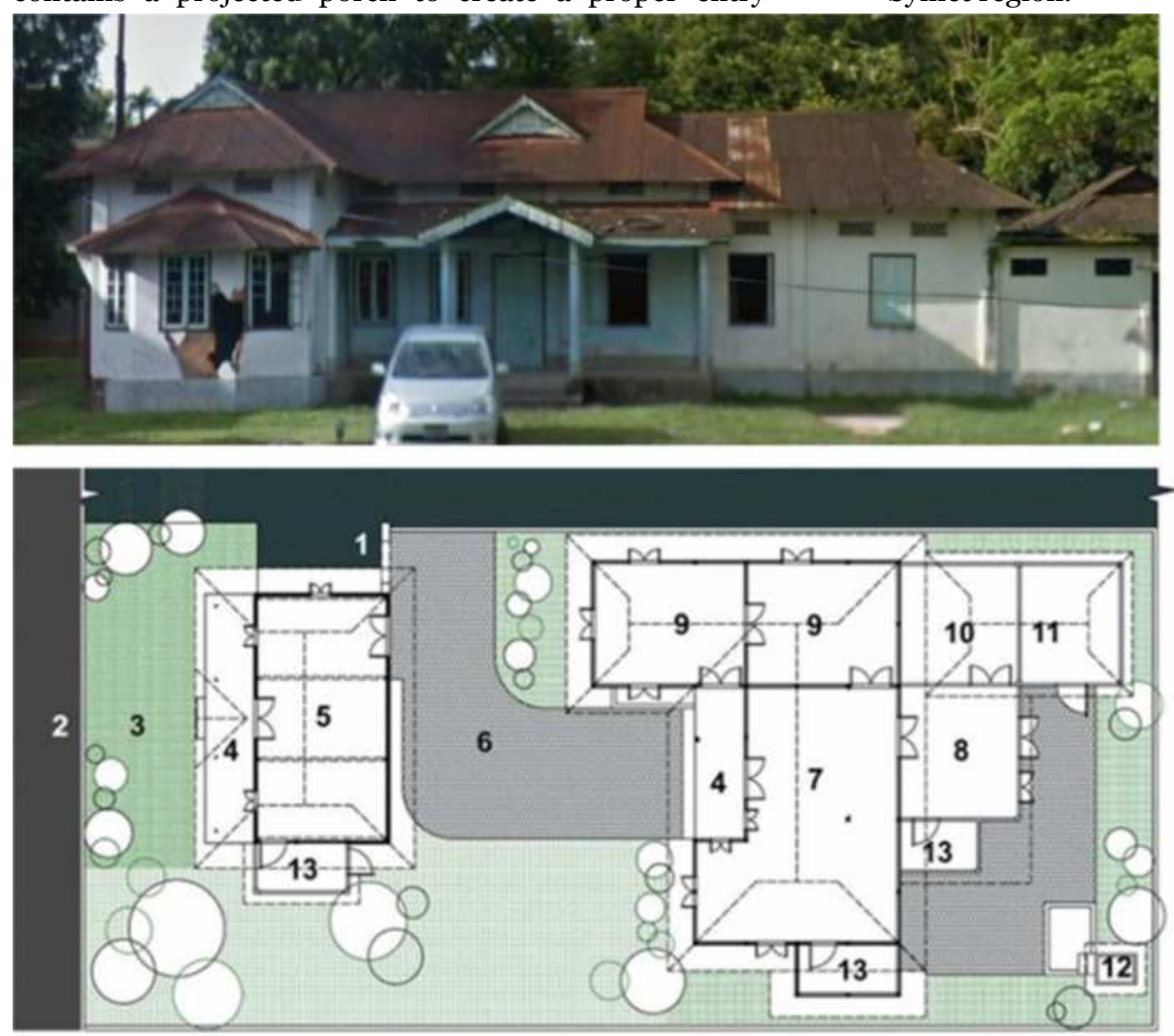
1. Entry-private
2. Entry-public
3. Outdoor court yard
4. Semi-outdoor Verandah
5. Out-house
6. Inner court
7. Living
8. Dining (Extended)
9. Bed room
10. Bed room (Extended)
11. Kitchen (Extended)
12. Toilet \& wash Zone
13. Toilet (Extended)

Fig. 8. Spatial sequences of 'Bangla Baton' house complex (Saad Udd in Chawdhury Residence, 1924).

Construction technique. One of the unique features of the 'Bangla Baton' houses is the modular construction technique. The construction is carried out in three of four phases, which comprises the foundation work of erecting the angle bars, building the frame structure for a wall, settling the roof system with the bamboo fence or wood planks supported by rafter and purlins, and last, plastering the fabricated structure with cement and lime (Fig. 9). The foundation was typically shallow, with a plinth of masonry structure and sometimes there was no foundation as they were lightweight structures. To strengthen the Baton wall, sometimes masonry half walls were constructed at the bottom, which also helped in the maintenance work. Local artisan and masons engineer the entire process, and that represents significant influences of traditional craftsmanship. In the previous times, the structural system was purely timber post-beam frames, and the walls were made by bamboo mesh, but later, to strengthen the joints and take larger spans, iron angle bars were introduced. Most houses have bambooreinforced concrete posts in their semi-outdoor areas, 
and sometimes, exposed ornamented timber posts were used. Timber posts were replaced by a concrete post, but the details resembling the old ones were maintained.

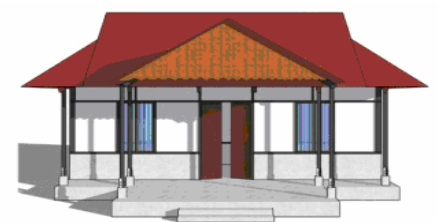

Front Elevation

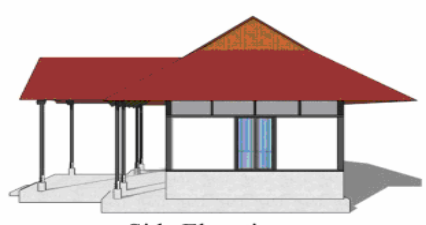

Side Elevation

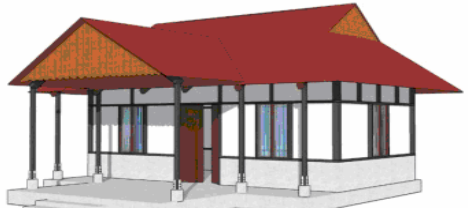

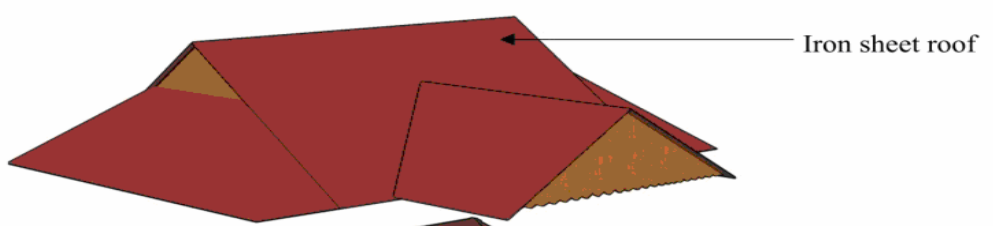

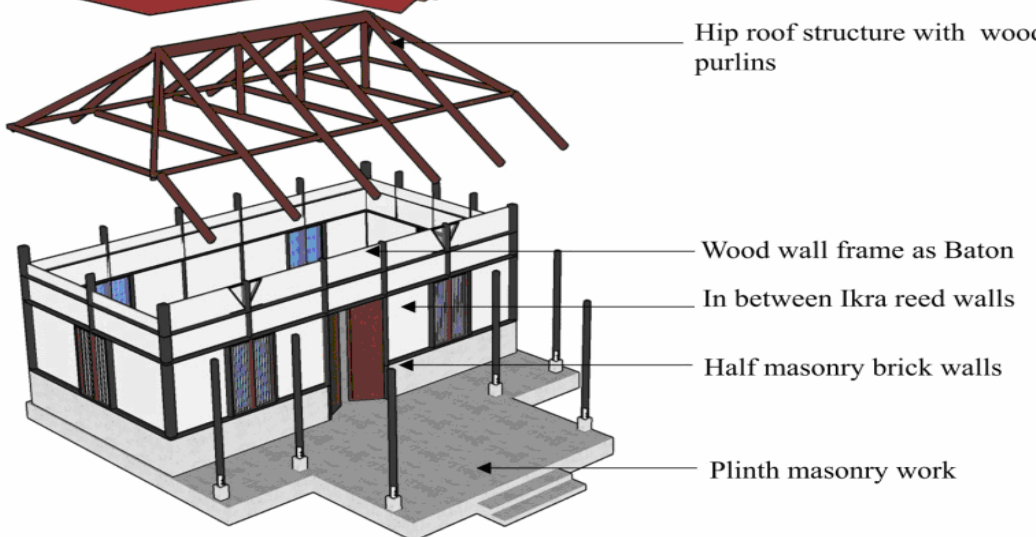

Fig. 9. Representation of the structural system of ‘Bangla Baton' house.

\subsection{Aesthetic significance}

The aesthetic significances of any heritage properties are derived from both visual and non-visual aesthetic qualities. The visual qualities of any building include the form, scale, relationship between

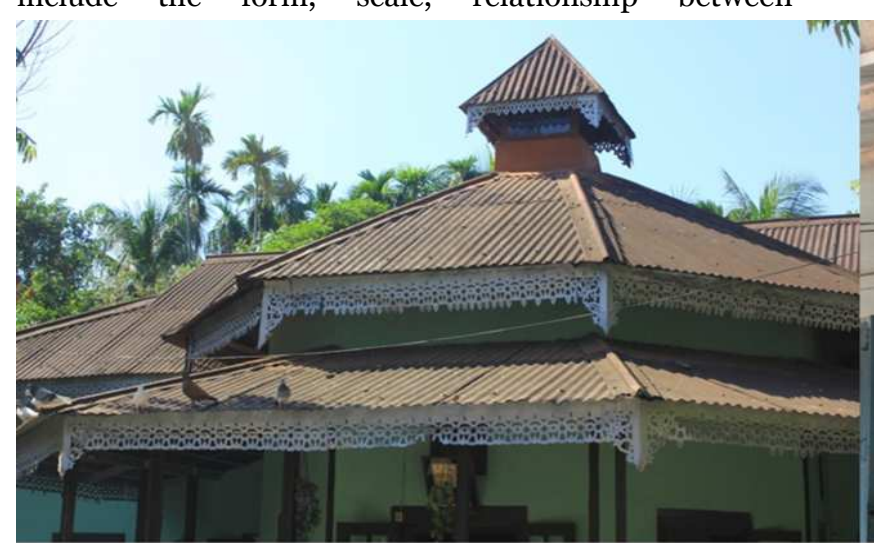

components, unity, contrast, colour, texture, and material. The non-visual aesthetic qualities can include sound, touch, and sense of place, symbolism, smell, myth, or qualities that can influence the perception on the heritage property. The Baton Houses possess a robust visual identity with particular aesthetic features.

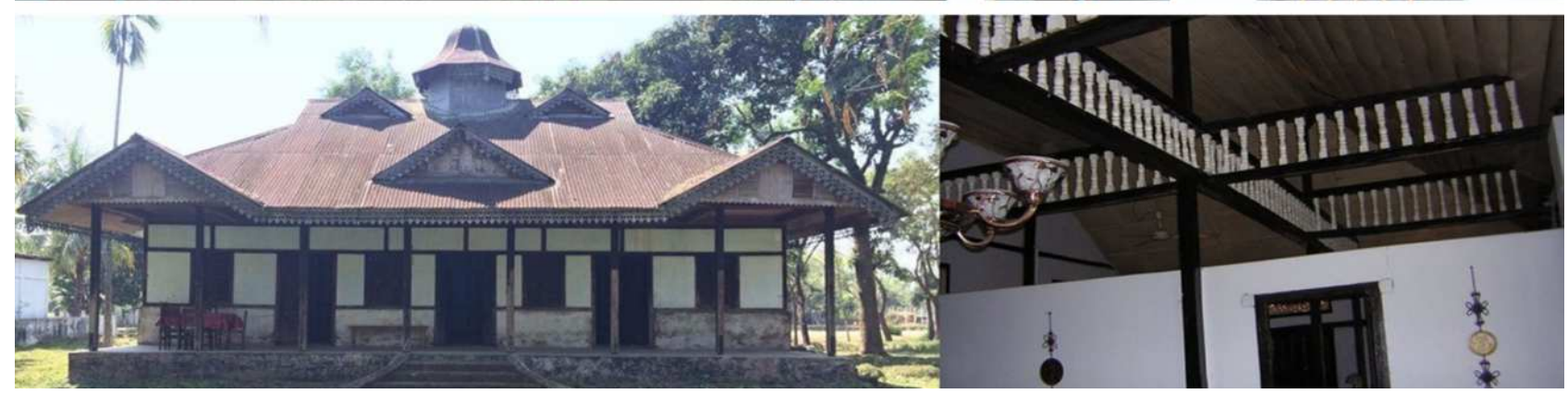

Fig. 10. Symbolism, ornamentation details of 'Bangla Baton' house.

Visual expression \& material culture. The fair expression with the contrast of dark-coloured linear wooden framing is iconic and highlights the features of 'Bangla Baton' house. It is mostly a compact type singlestory structure but, in most cases, a visual expression of 'double-height' is experienced from the outside because of its loftier internal space (height varies from 4 to 5 meters) and the structural expression of the exposed timber panel walls and posts. The wall is popularly known as the 'Ikra wall', made of dried reed called 
Vernacular Architecture as Cultural Heritage:

An Interpretation of Urban Vernacular 'Bangla Baton' Houses of Sylhet City, Bangladesh

Journal Settlements and Spatial Planning, vol. 12, no. 1 (2021) 35-49

'Ikra', mud plastering, and wooden panelling (Kaushik and Babu, 2009). The walls previously used to be covered with a mixture of mud and lime, but later they were replaced by cement and paint for maintenance. Well-seasoned wood and sometimes bamboo fencing false ceiling materials were used. Locally made iron sheets were the most commonly used for roof construction. The structural system and applied materials give a common visual expression of a black and white grid surface. These expressions give a brand outlook of this specific type of house form.

Ornamentation and symbolism. The 'Bangla Baton' house set itself up as an example of elegance and sophistication of a particular group of urban society in Sylhet. More particularly, the roofing style with gables, floral ornamented drop at edges, wood curving indoors, window panels and posts, iron sheet, cut ornamentation, clerestory light of high windows and ventilators show a significant influence of the traditional craftsmanship (see Fig. 10). A significant feature often found in this type of house form is the north-eastern graphical patterns primarily seen in the local ethnic houses. These specific ornamentation features are carried in the regional and cultural

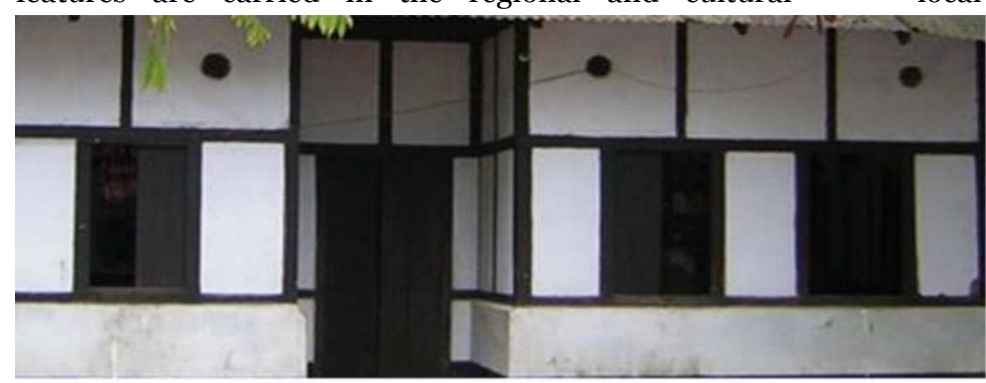

a) Baton frame wall made from Ikra

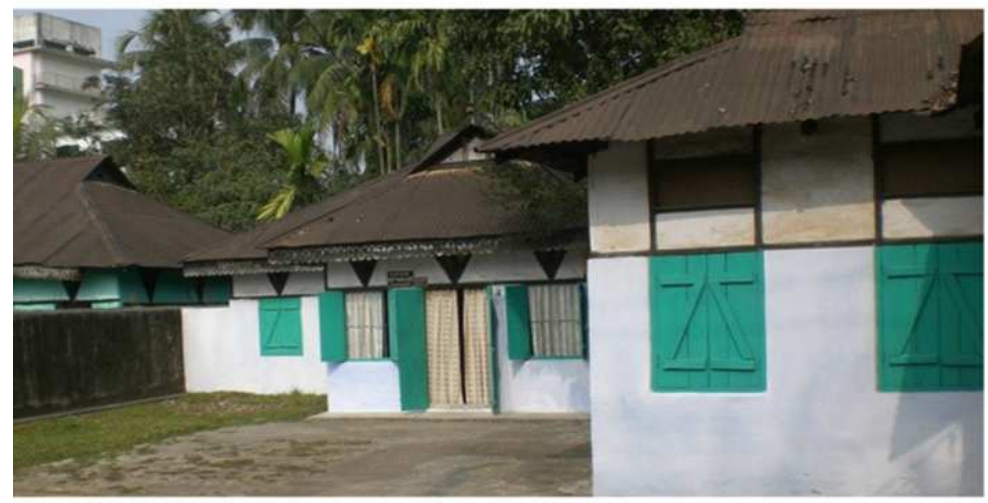

c) Light weight and low height construction symbolism of this particular region. Many old houses are often crowned with a small pyramidal light chamber on their roofs. This light chamber gives a unique aesthetic character to the building elevation, symbolizing the region's hilly topography.

\subsection{Scientific significance}

A heritage form can be considered to have scientific significance if it is likely that it has the potential for further research or can be subject of analysis with the help of its associated documentary evidence. Studying the 'Bangla Baton' house may enhance our understanding of Sylhet's history and its relationship with the region's other evolved vernacular housing styles. Moreover, the unique construction technology, environmental and climatic solutions, and the seismic design principles may be helpful as solutions for similar topographic or climatic zones for many other countries or areas.

Seismic design principles. In the case of Sylhet city, a part of most earthquake venerable areas (zone 3), the earthquakes have been a vital factor in shaping the local architecture (Al-Hussaini et al., 2012).

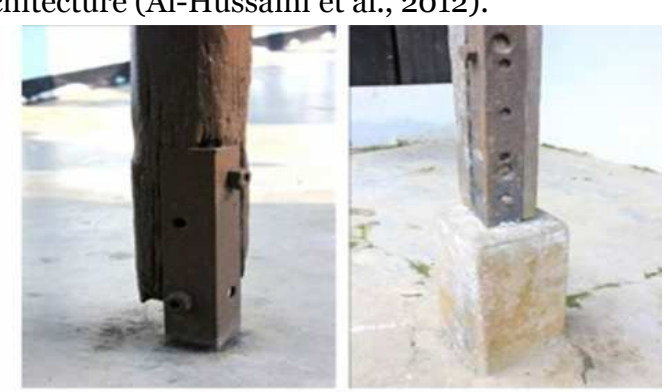

b) Base isolation from post

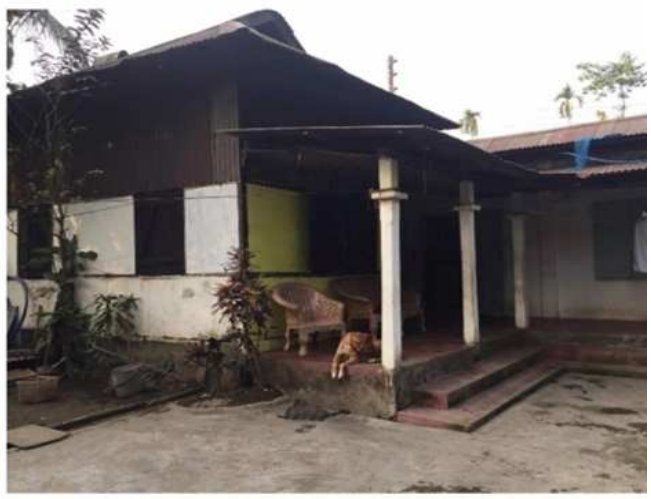

d) Post Lintel construction

Fig. 11. Earthquake resilient construction techniques in Bangla Baton houses.

Bangla Baton' houses have adopted multiple unique features, which are used as an effective solution to the region's earthquake vulnerability. The regular, symmetrical planning, less opening, and lightweight structure make the houses more resilient. The most emphatic features of 'Bangla Baton' houses are the scientific innovation of lightweight walls using simple local methods. The walls are made of wooden baton frames in-filled with reed 'Ikra' walls (Kaushik and Kaja, 2016). This type of wall construction has proven to be exceptionally well functioning against earthquakes. Even at wide lateral drifts, the 'Ikra' walls in the house do not damage the surrounding timber frame because of their weight, so that wall joints remain unharmed (see Fig. 11). The wooden pillars are separated from the concrete foundation column through base isolation 
techniques (Kakkad and Sanghvi, 2011). This connection allows a particular rotation during the earthquake so that the structure does not collapse. A masonry half wall is embedded at the bottom part of the outer wall in many houses to strengthen the Baton wall. Various joinery connections between vertical and horizontal members also make these houses perform more flexibly during the earthquakes (Chand et al., 2017). These improvisations are prominent examples of how modern technologies mixed with traditional building systems can make architecture more resilient and sustainable.

\subsection{Environmental \& climatic solutions}

Solar heat gain minimization. The effect of the sun is considerably reduced by the double roof attic of the house structure. Their large projected roof overhangs and wide shaded veranda, the availability of extended shading, and the thermal insulator walls contribute to the excellent thermal properties and reflect a sustainable response to the ecological and environmental problems.

Rain protection. The compact planning of rooms for maximum shelter, the extended semi-outdoor veranda and the extended roof ends not only secure the house from the heat effect of the sun, but also from rain.
Pitched roofs are joined to each other to build a shared shelter. This shows that heavy rainfall in this region has a significant impact on this type of vernacular housing. A rainwater drainage system is also present in most households. Long drop walls are used for shielding walls from the driving rain.

Ventilation. Houses are provided with large windows and triangle high windows with mosquito net for cross ventilation to get proper ventilation. Houses are arranged mainly on the north-south direction. House units are separated into smaller forms to get a free flow of the air. The courtyard and the distribution of semi-outdoor spaces are designed to get cool air. On the roof edge, a louvered gable end is used.

\subsection{Socio-cultural significance}

Social dimensions and cultural norms have always been vital indicators for creating vernacular architecture around the world. The socio-cultural significances in vernacular buildings consist of symbolic, spiritual, or moral values associated with a place and valued by a particular cultural group (DEHP, 2013).

The socio-cultural values are well expressed through the vernacular language of the 'Bangla Baton' houses (Table 2).

Table 2. Influence of socio-cultural context on the spatial morphology of Bangla Baton houses.

\begin{tabular}{|c|c|}
\hline Values and beliefs & Spatial pattern and morphology \\
\hline $\begin{array}{l}\text { Sense of joint family } \\
\text { culture and values }\end{array}$ & $\begin{array}{l}\text { - Compact house plan and shared family spaces support joint family values } \\
\text { - Rooms are often multifunctional rather than individual }\end{array}$ \\
\hline $\begin{array}{l}\text { Privacy consideration } \\
\text { and religious norms }\end{array}$ & $\begin{array}{l}\text { - Separation of inhouse and outhouse with inner courtyard to ensure privacy and preserve the family value } \\
\text { - In small houses, the extended semi-outdoor often provides a buffer and sense of control between outdoor } \\
\text { and indoor } \\
\text { - Vegetations are often used as a natural barrier, both functional and visual, from the street side } \\
\text { - Defined space for prayer }\end{array}$ \\
\hline Age and gender & $\begin{array}{l}\text { - Strict privacy women are maintained in some houses } \\
\text { - Very often, the house owner of the family head gets the larger room } \\
\text { - Kitchen, prayer, bathing spaces are located at the backside for gender privacy } \\
\text { - Dedicated resting space for elderly members is often provided } \\
\text { - Dedicated space is allocated for younger }\end{array}$ \\
\hline Family growth & - The modular construction allows easy extension and joining of a new house \\
\hline $\begin{array}{l}\text { Social interaction and } \\
\text { hospitality }\end{array}$ & $\begin{array}{l}\text { - Particular presences of guest rooms, guest accommodation to allow external guests } \\
\text { - Large common spaces allocated for family ceremony or social events } \\
\text { - The central porch, semi-outdoor front, visually transparent entry gate gives a welcoming approach } \\
\text { towards the house }\end{array}$ \\
\hline $\begin{array}{l}\text { Cleanliness and } \\
\text { sanitation }\end{array}$ & $\begin{array}{l}\text { - Cleanliness hygiene is strictly maintained. Often shoes are kept outside the room } \\
\text { - Usually, toilet spaces are separated from the main structure - detached space for bathing }\end{array}$ \\
\hline $\begin{array}{l}\text { Social unity and } \\
\text { humble appearance }\end{array}$ & $\begin{array}{l}\text { - The similarity of an external appearance of houses makes sense of social unity } \\
\text { - Hierarchy of symmetricity, balance, axis, the scale gives an ordered discipline of the society } \\
\text { - Large or small, rich or poor, consistency of style highlights social equity and humbleness of past }\end{array}$ \\
\hline Cultural symbol & $\begin{array}{l}\text { - Regional graphical patterns are used for ornamentation } \\
\text { - A small light chamber on the roof gives a unique identity and recognition } \\
\text { - The hierarchy of pitched roofs resembles the regional hilly topography }\end{array}$ \\
\hline
\end{tabular}

Through the physical survey and interpretation of the planning layout, we learned that the spatial 44 distribution of the traditional 'Bangla Baton' houses consists of two separate zones - the inner house and the 


\section{Vernacular Architecture as Cultural Heritage: \\ An Interpretation of Urban Vernacular 'Bangla Baton' Houses of Sylhet City, Bangladesh \\ Journal Settlements and Spatial Planning, vol. 12, no. 1 (2021) 35-49}

outer house. Often a private court divides these two separate areas. The outhouse is placed at the frontal part and serves for formal living, two or three guest beds, storage, a wide veranda with a strong sense of privacy. So, the public area, accommodation for guests, and family spaces are consciously separated from the individual rooms. Female dominated spaces like kitchen, prayer spaces, and bathing spaces are located deeper to provide adequate gender privacy.

'Bangla Baton' houses, with their prominent features, contribute significantly to the preservation of identity and represent some of the cultural assets of a particular group of urban society in Sylhet. They carry a landmark quality given by the contrast expression of walls, ornamented patterns, and integrated spatial organization in accordance with the sense of place that illustrates the surviving socio-cultural fabric of the local community of Sylhet (Table 2). This house form symbolically represents the past and present of traditional housing technology in this region. The internal layout and space distribution also represent the spiritual sense of the society. The sense of privacy and strong introversion of spaces give features to the traditional Islamic practice of 'Pardah,' a socio-religious female solitude tradition (Britannica, 2008). Nevertheless, the similarity of external appearances, semi-outdoor space, and the inviting entry resemble a strong sense of communal identity (Table 2).

\subsection{Summary of significance indicators}

The authors concluded the summary of significances with the descriptive analysis of the outcomes of the survey regarding the 'Bangla Baton' house. The indicators that support the significance were identified and listed. Table 3 shows the significance indicators of 'Bangla Baton' houses in relevance to cultural significance criteria. The significance indicator is both tangible and intangible. Architectural elements, construction history, material culture falling under each criterion show their significant value and attributes to be treated as cultural heritage.

Table 3. Summary of significances of Bangla Baton houses.

\begin{tabular}{|c|c|c|}
\hline Criterion & $\begin{array}{c}\text { Type of cultural } \\
\text { heritage significance }\end{array}$ & Significance indicators of 'Bangla Baton' houses \\
\hline $\begin{array}{l}\text { a). The place is important } \\
\text { in demonstrating the } \\
\text { evolution or pattern of the } \\
\text { urban history of Sylhet }\end{array}$ & $\begin{array}{l}\text { Historical } \\
\text { Scientific }\end{array}$ & $\begin{array}{l}\text { - Being one of the oldest types of settlements in Bangladesh } \\
\text { - Recalling the fact that Sylhet was an integral part of the eastern Indian } \\
\text { region } \\
\text { - Representing the exceptional traditional housing pattern of urban Sylhet }\end{array}$ \\
\hline $\begin{array}{l}\text { b). The place demonstrates } \\
\text { rare, uncommon, or } \\
\text { endangered aspects of the } \\
\text { cultural heritage of Sylhet }\end{array}$ & $\begin{array}{l}\text { All aspects of cultural } \\
\text { heritage significance }\end{array}$ & $\begin{array}{l}\text { - Elegant image showing a particular group of urban society } \\
\text { - Signature landmark quality } \\
\text { - Associated with intangible values like myth, belief, urban images } \\
\text { - Evidence of undocumented and forgotten historic construction systems }\end{array}$ \\
\hline $\begin{array}{l}\text { c). The place has the } \\
\text { potential to yield } \\
\text { information that will } \\
\text { contribute to an } \\
\text { understanding of the urban } \\
\text { history of Sylhet }\end{array}$ & $\begin{array}{l}\text { Scientific } \\
\text { Historical }\end{array}$ & $\begin{array}{l}\text { - Potential to support knowledge referred to housing construction } \\
\text { technology that will aid in a comparative evaluation of identical places } \\
\text { - This house form is closely associated to urban development during British } \\
\text { ruled India } \\
\text { - Shows pieces of evidence of early urban development of Sylhet city }\end{array}$ \\
\hline $\begin{array}{l}\text { d). The place is important } \\
\text { in demonstrating the } \\
\text { principal characteristics of } \\
\text { a particular class of cultural } \\
\text { places }\end{array}$ & $\begin{array}{l}\text { Architectural } \\
\text { Historical }\end{array}$ & $\begin{array}{l}\text { - Design innovations and context responsive solutions } \\
\text { - Roofing style with gables, floral ornamented drop at edges, C. I sheet cut } \\
\text { ornamentation } \\
\text { - Inner courtyard to create a buffer zone between semi-private and private } \\
\text { - Regular form and modular structure } \\
\text { - A unique construction technique of earthquake-resilient houses } \\
\text { - Represent the socio-cultural ethnicity, family values of urban Sylhet }\end{array}$ \\
\hline $\begin{array}{l}\text { e). The place is important } \\
\text { because of its aesthetic } \\
\text { significance }\end{array}$ & $\begin{array}{c}\text { Aesthetic } \\
\text { Architectural }\end{array}$ & $\begin{array}{l}\text { - Distribution of open spaces as circulations } \\
\text { - A specific pattern of the separate public to private zoning } \\
\text { - Presence of outhouse for professional practice to ensure secured and } \\
\text { limited public entry } \\
\text { - Adaption of new housing technology in a creative manner } \\
\text { - The unique visual language of black and white grid techniques } \\
\text { - Use of lighthouses on top as a symbol }\end{array}$ \\
\hline $\begin{array}{l}\text { f). The place is important } \\
\text { in demonstrating a high } \\
\text { degree of creative or } \\
\text { technical achievement at a } \\
\text { particular period }\end{array}$ & $\begin{array}{l}\text { Aesthetic } \\
\text { Architectural } \\
\text { Other }\end{array}$ & $\begin{array}{l}\text { - The invention of earthquake resilience techniques of construction } \\
\text { - Introduction of prefabricated modular construction principles } \\
\text { - Charms of high windows, ventilators, and triangle-shaped high windows } \\
\text { - A visual expression of 'double-height' is encountered from the outside }\end{array}$ \\
\hline
\end{tabular}




\begin{tabular}{|c|c|c|}
\hline $\begin{array}{l}\text { g). The place has a strong } \\
\text { or special association with } \\
\text { a particular community or } \\
\text { cultural group for social, } \\
\text { cultural, or spiritual } \\
\text { reasons }\end{array}$ & Social & $\begin{array}{l}\text { - Important to the community as a landmark, marker, or signature } \\
\text { - Highlights the traditional culture of 'Pardah' of the old traditional society } \\
\text { community or cultural group } \\
\text { - Symbolically representing the past in the present of vernacular housing of } \\
\text { Sylhet } \\
\text { - Represent 'a shared family relationship' } \\
\text { - Shows a collective social neighbourhood of old Sylhet city } \\
\text { - The houses offer a deep impression of cultural cooperation between Sylhet } \\
\text { and the Assam region }\end{array}$ \\
\hline $\begin{array}{l}\text { h). The place has a special } \\
\text { association with the life or } \\
\text { work of a particular person, } \\
\text { group, or organization of } \\
\text { importance in the history } \\
\text { of Sylhet }\end{array}$ & Historical & $\begin{array}{l}\text { - Strongly influenced by the Assamese style house of the north-eastern part } \\
\text { of India } \\
\text { - Many old schools, libraries, office buildings are made with this similar } \\
\text { style } \\
\text { - Many houses are part of the political past of Sylhet city } \\
\text { - Few buildings are transformed to museums of local history }\end{array}$ \\
\hline
\end{tabular}

\subsection{Sustainability principles of 'Bangla Baton' houses}

Over the past few decades, sustainability has been a major concern for architects around the world, since architecture is by itself sustainable and architects are looking into a vernacular building to find sustainable solutions (Salman, 2018). Vernacular architecture is built on sustainable principles of minimal resource consumption, giving maximum attention to climatic issues while satisfying the human needs (Salman et al., 2016). The architecture of 'Bangla Baton' house encompasses several sustainability aspects such as environmental sustainability, seismic design principles, energy conservation, ecology, regional features, which are essentially context-based. The housing technology of this house form is well suited to the cultural, social, and physical characteristics of the Sylhet region.

'Bangla Baton' houses show sensitivity towards regional micro-climate. Sylhet region is known for its warm, humid climate and substantial rainfall over the year. The design principles and construction technology of these houses strongly consider the climatic issues like heavy monsoon rainfall, temperature, and moderate airflow of this region (Fig. 12).

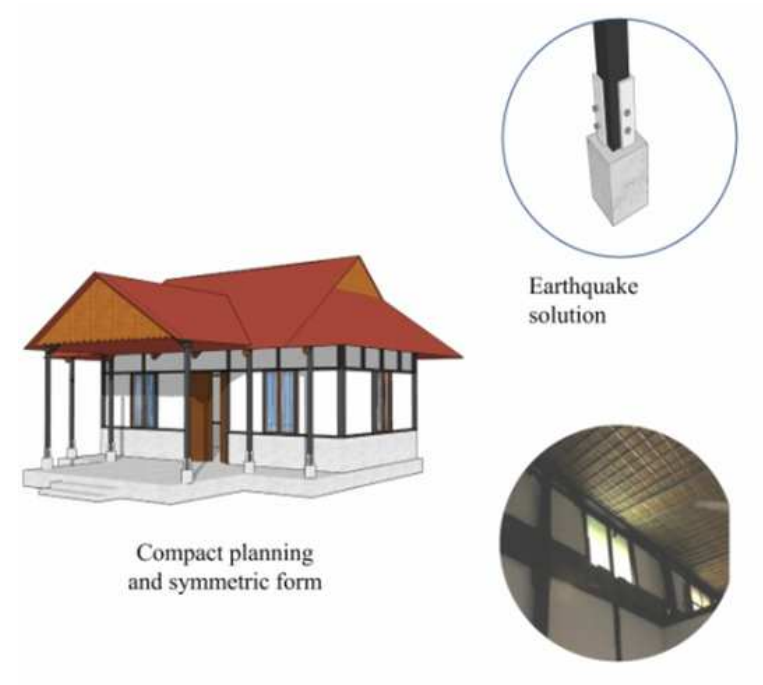

Day lighting and ventilation through high window
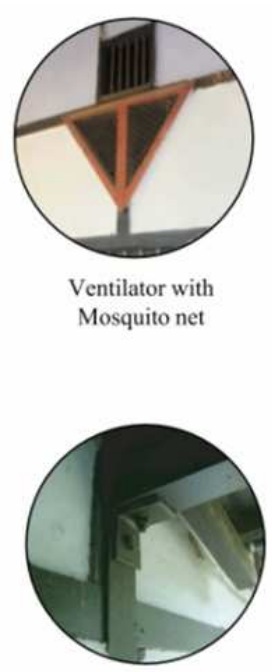

Pre fabricated, durable, modular construction

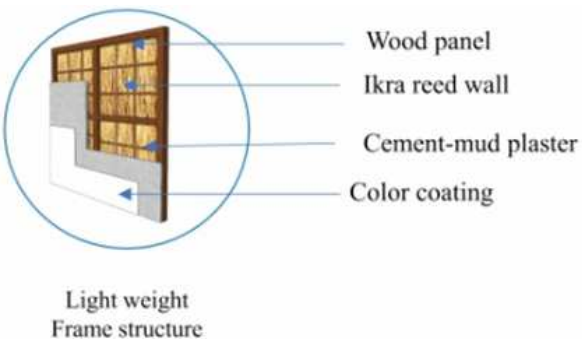

Frame structure

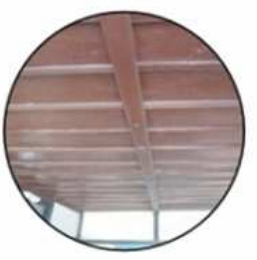

Low thermal material ceiling

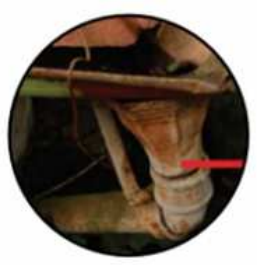

Rain water collection system

Fig. 12. Sustainable climatic solution and prefabricated construction techniques.

For example, in the compact system of internal planning, pitched roofs directly respond to the more extended monsoon season in this area. Most of the houses have rainwater collection system by connecting a pipe to the roof edges and the water storage on the ground. Besides, passive solar design techniques are introduced. The longer portions of the houses usually face the south so that sufficient air and light can easily enter the living units. Courtyards and shaded corridors work as natural cooling components by protecting the house units from the sun's direct heat. This type of house form is a low rise, lightweight construction, and isolated from the base, which is the sustainable treatment for earthquake vulnerability of Sylhet region. Timber frame structure and vegetable fibre are often used in construction because of the availability of wood and bamboo on local markets. Because of its simple modular construction process, which is engineered by 
Vernacular Architecture as Cultural Heritage:

An Interpretation of Urban Vernacular 'Bangla Baton' Houses of Sylhet City, Bangladesh

Journal Settlements and Spatial Planning, vol. 12, no. 1 (2021) 35-49

local craftsmen and masons, it is easy to build. The components and materials are prefabricated and assembled on site. Because of the modular design, any part of the house can be easily modified. Previously, iron sheet was used as a surface material to ensure the cost-effectiveness of the house.

Table 4. Sustainability features of the 'Bangla Baton' houses.

\begin{tabular}{|c|c|c|}
\hline $\begin{array}{c}\text { Key } \\
\text { Sustainability } \\
\text { determinants }\end{array}$ & $\begin{array}{l}\text { Design } \\
\text { issues }\end{array}$ & Architectural characteristics \\
\hline $\begin{array}{l}\text { Seismic } \\
\text { vulnerability } \\
\text { resilience }\end{array}$ & $\begin{array}{l}\text { Earthquake } \\
\text { vulnerability }\end{array}$ & $\begin{array}{l}\text { - Lightweight construction techniques using local materials like mud, reed, and bamboo give } \\
\text { earth quack venerability } \\
\text { - Use of baton structure with wall frame } \\
\text { - Symmetric planning with a single height structure } \\
\text { - The connection between foundation and column is separated with extra flexible joints }\end{array}$ \\
\hline \multirow{3}{*}{$\begin{array}{l}\text { Climate } \\
\text { responsiveness }\end{array}$} & $\begin{array}{l}\text { Heavy } \\
\text { monsoon } \\
\text { rainfall }\end{array}$ & $\begin{array}{l}\text { - Houses are attached and planned in a compact formation to reduce circulation and ensure } \\
\text { shades } \\
\text { - Interlocking pitch roof gives rainwater protection } \\
\text { - Extended Semi outdoor spaces and long drop wall interrupt driving rain } \\
\text { - Prohibition of rainwater harvesting }\end{array}$ \\
\hline & Temperature & $\begin{array}{l}\text { - Double Roof attic gives buffer insulation } \\
\text { - Extended shadings against sun angle } \\
\text { - Thermal Insulator walls using brick, reed, mud, wood }\end{array}$ \\
\hline & $\begin{array}{l}\text { Moderate } \\
\text { airflow and } \\
\text { daylight }\end{array}$ & $\begin{array}{l}\text { - Louvered Gable end on roof edge to ensure } \\
\text { - Triangular high window with mosquito net } \\
\text { - A larger window for cross ventilation }\end{array}$ \\
\hline \multirow{4}{*}{$\begin{array}{l}\text { Affordable } \\
\text { construction } \\
\text { technology }\end{array}$} & $\begin{array}{c}\text { Structural } \\
\text { stability }\end{array}$ & $\begin{array}{l}\text { - A shallow brick foundation gives stability } \\
\text { - The lower part is made heavier than the upper part }\end{array}$ \\
\hline & $\begin{array}{l}\text { Availability of } \\
\text { material }\end{array}$ & $\begin{array}{l}\text { - The timber frame structure for the availability of wood } \\
\text { - Use of vegetable reed fibers 'Ikra' inside wall } \\
\text { - Variety of locally available materials used like wood, cement, steel, brick, limestone, mud } \\
\text { - Traditional materials are mixed with modern materials. }\end{array}$ \\
\hline & $\begin{array}{c}\text { Rapid } \\
\text { construction }\end{array}$ & $\begin{array}{l}\text { - Modular planning concept helps rapid construction } \\
\text { - Prefabricated materials, joints are commonly used for construction and assembled on site }\end{array}$ \\
\hline & $\begin{array}{c}\text { Easy } \\
\text { maintenance }\end{array}$ & - The structure is made part by part by assembling modules. So they are easy to replace \\
\hline
\end{tabular}

Sustainability lessons learned from the 'Bangla Baton' houses are of immense importance. Besides historical and cultural values, these houses also have emerged as great sustainable housing models in this context. From a perspective of building and urban sustainability, the use of regional building materials, energy efficiency, natural thermal insulation techniques have strengthened the building durability and the character of environmentally friendly. These buildings are easy to repair for their modular character. This means that any part of the building can be changed or replaced easily. During the survey and the interview, the house owners expressed satisfaction over indoor thermal quality and ventilation. Besides climatic comfort, affordability is another reason low-income families still prefer to live in these houses. The compact nature of internal planning and interconnected built forms require less ground area for the construction. This measure allows growing in a dense urban context with a very high land price. Sylhet is a vulnerable earthquake area with a considerable number of mild earthquake incidents every year. However, not a single 'Bangla Baton' house was reported damaged due to an earthquake in a few decades. The 'Bangla baton' houses show much respect and sensitivity to the local microclimate with their bioclimatic solutions, compared to the so-called 'modern houses'. These sustainability lessons learned from the 'Bangla Baton' houses can inspire modern-day architects to apply and adapt sustainable measures in their construction design. These houses are old but not obsolete as they are still functioning as an excellent example of sustainable architecture.

Table 4 presents a summary of the sustainability features of the 'Bangla Baton' houses, identified by the authors during the site survey.

\section{CONCLUSION}

Every type of architecture is a reinterpretation of the historical architectural heritage, which is usually shared with related cultures. The knowledge of this 
heritage is indispensable in every attempt to understand particular local development, both in its formal manifestations and the related symbolic meanings (Schefold et al., 2004). Interpretation, as one of the most useful ways of encouraging appreciation of a 'cultural heritage element, explains its significance by analyzing its cultural assets. Based on the analysis of architectural properties, historic, cultural and environmental significances, it is clearly understood that 'Bangla Baton' can be introduced as an effective form of 'Cultural Heritage'.

Being one of the oldest settlements of Bangladesh, the 'Bangla Baton' house has always had the potential to get explored and appreciated for its earliness, regional importance, and exceptionality and to contribute to the knowledge related to housing construction technology. These house forms have an influential contribution to local vernacular housing technology. This particular house type is the outcome of the evolving pattern of the living style, social, and cultural practices. 'Bangla Baton' house form demonstrates the individuality of the local community of the Sylhet region by proving its existence as a 'landmark' and highlighting its traditional culture with its elegant ornamentation, contrast expression of the exterior walls, and the visual appearance of 'doubleheight. By distributing open spaces as circulations, using a specific pattern of the separate public to private zoning, secured and controlled public access, and adopting new housing technology, these houses present their architectural innovations associated with aesthetic quality. To enhance appreciation and awareness of the local community and the government, this paper identifies the important qualities of this house form by using the internationally accepted criteria.

The identified criteria show that the 'Bangla Baton' houses are unique examples of architectural innovation with their context-responsive design features, and exceptional aesthetical qualities. This research presents a thorough analysis, along with the assessment of sustainability factors, by explaining the importance and urgency to take necessary steps to preserve this valuable house form. The study outcome may also be a helpful document or guideline for taking the further initiative to conserve this threatened vernacular housing technology and suggests sensitive approaches to choose for conservation management and planning. However, these significant qualities should be enhanced by the integration of the sustainability factors, environmental and ecological solutions, energy and cost-efficiency, and material availability. Considering the study findings, it would be appropriate to mention that the architectural system of the 'Bangla Baton' houses meets all the criteria to be interpreted as a cultural heritage asset. These houses are deeply connected with the local urban and political history. Since this study only gives a primary introduction to this housing style, further studies need to be carried out. It is recommended that, due to the cross border nature of the heritage sites, an international conservation initiative between Bangladesh and India might be more helpful to save this unique heritage.

\section{ACKNOWLEDGEMENTS}

The authors want to acknowledge the students of the Architecture Department, Shahjalal University of Science and Technology for actively taking part in the field survey. The authors also highly acknowledge the contributions of SUST research centre, Shahjalal University of Science and Technology for funding the initial survey and research. The authors also want to thank anonymous reviewers and editors of this paper for their valuable suggestions.

\section{REFERENCES}

Achuthan N. (2016), Amazing Facts: Traditional Bamboo Houses of Assam. The Hindu Group. URL: https://roofandfloor.thehindu.com/real-estateblog/. Accessed on 6.10.2020

Al-Hussaini T. M., Hossain T. R., Al- Noman N. M. (2012), Proposed Changes to the Geotechnical Earthquake Engineering Provisions of the Bangladesh Building Code. Geotechnical Engineering Journal of the SEAGS \& AGSSEA, 43(2), 1-7. URL: http://seags.ait.asia/e-journal/2012/jun/SEAGS-E-

Journal-2012-June-01-07-Tahmeed-Tahsin-Nayeem.pdf

AL-Mohannadi A., Furlan R., Major M. D. (2020), A Cultural Heritage Framework for Preserving Qatari Vernacular Domestic Architecture. Sustainability, $\quad 12, \quad 1-26 . \quad$ DOI: https://doi.org/10.3390/su12187295

Archinomy (2013), Traditional House in Assam. URL: https://www.archinomy.com/case-studies/traditionalhouse-in-assam. Accessed on 4.11.2020

Bilham R. (2008), Tom La Touche and the Great Assam Earthquake of 12 June 1897: Letters from the Epicenter. Historical Seismologist. URL: http://www.seismosoc.org/Publications/SRL/SR

L_79/srl_79-3_hs.html. Accessed on 12.10.2020

Britannica (2008), Purdah Islamic Custom. (Encyclopedia Britannica).

URL: https://www.britannica.com/topic/purdah.

Accessed on 8.11.2020

Chand B., Kaushik H. B., Das S. (2017), Experimental study on traditional Assam-type wooden house for seismic assessment. $16^{\text {th }}$ World Conference on Earthquake. Santiago Chile. URL: https://www.wcee.nicee.org/wcee/article/16WCEE/WC EE2017-2431.pdf 
Vernacular Architecture as Cultural Heritage:

An Interpretation of Urban Vernacular 'Bangla Baton' Houses of Sylhet City, Bangladesh

Journal Settlements and Spatial Planning, vol. 12, no. 1 (2021) 35-49

Christie W. (2017), Safeguarding Indigenous Architecture in Vanuatu. UNESCO Office in APIA. Office for the Pacific States. URL: https://unesdoc.unesco.org/ark:/48223/pfoooo2 48144. Accessed on 8.10.2020

Das N., Pal S., Bora S. S., Walling O. (2014), Study of Traditional Houses in Assam. Journal of Civil Engineering and Environmental Technology, 1(4), 5358.URL:https://krishisanskriti.org/vol_image/13Jun20 1502065314.pdf

DEHP (2013), Assessing cultural heritage significance. Using the cultural heritage criteria. Department of Environment and Heritage Protection, Brisbane. Queensland Government. URL: https://www.qld.gov.au/_data/assets/pdf_file/oo3o/ 66693/using-the-criteria.pdf

Fielding N. (1993), Ethnography. In N. Gilbert, Researching Social Life. London: Sage Publications

Groat L., Wang D. C. (2001), Architectural Research Methodology. New Work: John Wiley \& Sons Inc. ISBN: 978-0471333654

Hussain M. A. (2014), Sylhet er Itihas. Dhaka: Utso Prokashan

ICOMOS (1999), Charter on the built vernacular heritage. Mexico: ICOMOS $12^{\text {th }}$ General Assembly. URL: http://ciav.icomos.org/wp-

content/uploads/2019/o4/charter-vernacular-en.pdf

ICOMOS (2017), Approach to conservation of twentiethcentury cultural heritage. Madrid - New Delhi Document. ICOMOS ISC20C. URL: http://www.icomosisc20c.org/pdf/madrid-new-delhi-document-2017.pdf

Kakkad M. D., Sanghvi C. D. (2011), Comparative Study of Bamboo (Ikra) Housing System with Modern Construction Practices. National Conference on Recent Trends in Engineering \& Technology. Gujarat. URL: https://www.bvmengineering.ac.in/misc/docs/publishe d-2opapers/civilstruct/struct/101078.pdf

Kalita J. (n.d.) The Great Assam Earthquake of 1897. Assam Portal. URL: https://assam.org/content/greatassam-earthquake-1897. Accessed on 20.11.2020

Kaushik H. B., Babu K. S. R. (2009), Housing report: Assam-type house. World Housing Encyclopedia. URL: http://www.worldhousing.net/WHEReports/wh100172.pdf

Kaushik P., Kaja N. (2016), Assam-type architecture; problems and prospects. International Advanced Research Journal in Science, Engineering and Technology, 3(9), 202-209. URL: https://iarjset.com/upload/2016/september16/IARJSET\%2039.pdf

MOIE (2019), Vernacular Architecture and its Significance as Cultural Heritage.
URL: https://shabait.com/2019/o2/12/vernaculararchitecture-and-its-significance-as-cultural-heritage. Accessed on 11.12.2020

Oliver P. (2006), Built to need meets: Cultural Issues in Vernacular Architecture. Oxford: Elsevier. DOI: https://doi.org/10.4324/9780080476308

Othman R. (2004), An applied ethnographic method for evaluating retrieval features. The Electronic Library, 22(5), 425-432.

DOI: https://doi.org/10.1108/02640470410561956

Rapoport A. (1969), House Form and Culture. Foundations of Cultural Geography Series. Prentice Hall Inc. New Jersey. ISBN: 978-0133956733

Saha K., Sobhan R., Alam A. (2013), Assessing sustainability as a cultural practice in architecture: An overview of Sylhet City, Bangladesh. Architecture Research, 3(3), 36-41. DOI: 10.5923/j.arch.20130303.03

Saha K., Sobhan R., Nahyan M. (2020), Morphology of a sacred urban landscape: the case study of Sylhet city, Bangladesh. Journal of Architectural Research and Education (JARE), 2(2), 111-120. Doi:https://doi.org/10.17509/jare.v2i2.26308

Salman M., Easterbrook S., Sabie S., Abate J. (2016), Sustainable and smart: Rethinking what a smart home is. Proceedings of ICT for Sustainability. Amsterdam. DOI: https://doi.org/10.2991/ict4s-16.2016.22

Salman M. (2018), Sustainability and Vernacular Architecture: Rethinking What Identity Is. In $\mathrm{K}$. Hmood, Urban and Architectural Heritage Conservation within Sustainability. IntechOpen. DOI: 10.5772/intechopen.82025.

URL:

https://www.intechopen.com/books/urban-andarchitectural-heritage-conservation-withinsustainability/sustainability-and-vernaculararchitecture-rethinking-what-identity-is

Schefold R., Domenig G., Nas P., (2004), Indonesian Houses: Tradition and Transformation in Vernacular Architecture. Singapore. Singapore University Press. ISBN: 978-9971692926

Sobhan R., Saha K., Nahyan M. (2013), The Architecture of 'Bangla Batton' Houses in Sylhet City: An Ethnographical Study on Vernacular House Form. Proceedings for $2^{\text {th }}$ Common Wealth Association of architects (CAA) Conference. Dhaka: CAA. URL: http://www.comarchitect.org/wp-content/dhaka2013/pdf_file/cd-\%20tp\%2006.pdf

Subhankar N., Amol G. (2013), Architecture of North East India: Vernacular Typologies. Journal of the Indian Institute of Architects, 84. URL: https://issuu.com/subhankarnag/docs/architecture-ofnorth-east-india-ve 